\title{
PENGARUH MODAL PSIKOLOGIS DAN PARTISIPASI ANGGARAN TERHADAP KEINGINAN UNTUK MEMBUAT SENJANGAN ANGGARAN
}

\author{
Jengger Woro Hapsari ${ }^{1}$, Alwi ${ }^{2}$ \\ ${ }^{1}$ Universitas Janabadra Yogyakarta, ${ }^{2}$ STIE Abdi Nusa Palembang \\ E-mail : ${ }^{1}$ Jeng.5687@gmail.com, ${ }^{2}$ alwi.palembang@gmail.com
}

\begin{abstract}
ABSTRACK
The study aimed at finding out the effect of psychological capital dan budgetary participation on the budgetary slack. The population are all of Kopertis in the Indonesia. There were about 84 respondents are budgetary team in Kopertis. The data were collected by using five instrument of questionnaries based on Likert-scales. Data quality test was made by using validity and reability. The hypotesis is tested using hypotesis T-Test. From the results of hypotesis tests it is concluded that (1) there was affect of psychological capital on the budgetary slack (2) there was not affect of budgetary participation on the budgetary slack.
\end{abstract}

Keywords : Psychological Capital, Budgetary Participation, Budgetary Slack

\begin{abstract}
ABSTRAK
Penelitian ini bertujuan untuk mengetahui pengaruh modal psikologis dan partisipasi anggaran terhadap keinginan untuk membuat senjangan anggaran.Populasi penelitian ini adalah LLDIKTI di Seluruh Indonesia. Sampel yang diambil adalah semua yang berpartisipasi dalam penyusunan anggaran, yang terdiri dari Kepala Bagian/Kepala Bidang, Kepala Subbag/Seksi dan Tim Penyusunan Anggaran dengan jumlah responden sebanyak 84 orang. Metode pengumpulan data dilakukan dengan kuesioner yang terdiri dari 5 instrumen dengan skala likert. Uji kualitas data yang digunakan yaitu uji validitas dan reabilitas. Hipotesis diuji menggunakan Uji Hipotesis T. Dari Hasil penelitian ini membuktikan bahwa (1) Terdapat pengaruh modal psikologis terhadap keinginan untuk membuat senjangan anggaran (2) Tidak pengaruh partisipasi anggaran terhadap keinginan untuk membuat senjangan anggaran.
\end{abstract}

Kata kunci : Modal Psikologis, Partisipasi Anggaran, Senjangan Anggaran 


\section{PENDAHULUAN}

Dinamika tata pemerintahan Republik Indonesia berdampak pada terjadinya restrukturisasi organisasi pemerintahan terutama pada periode ke 2 kepemimpinan Presiden Republik Indonesia Joko Widodo. Hal ini dialami juga oleh Lembaga Layanan Pendidikan Tinggi Wilayah II dimana sebelumnya berada di bawah Kementerian Riset, Teknologi dan Pendidikan Tinggi namun sekarang berada dibawah Kementerian Pendidikan dan Kebudayaan. Perubahan tersebut didasarkan pada Peraturan Presiden Nomor 72 Tahun 2019 tentang Kementerian Pendidikan dan Kebudayaan pasal 1, sebagai tindak lanjut dari Perpres tersebut telah diterbitkan Peraturan Menteri Pendidikan dan Kebudayaan Nomor 45 tahun 2019 tentang Organisasi Tata Kelola Kementerian Pendidikan dan Kebudayaan.

Keberadaan Lembaga Layanan Pendidikan Tinggi Wilayah II didasarkan pada Undang-Undang Nomor 12 tahun 2012 tentang Pendidikan Tinggi bagian kelima Pasal 57, Implementasi dari Undang-Undang Nomor 12 Tahun 2012 tentang Pendidikan Tinggi dan dalam rangka memperjelas peran Lembaga Layanan Pendidikan Tinggi diterbiutkan peraturan Menteri Riset, teknologi, dan pendidikan Tinggi nomor 15 tahun 2018 tentang Organisasi dan tata kerja Lembaga Layanan Pendidikan Tinggi. Sebelum menjadi Lembaga Layanan Pendidikan Tinggi (LLDIKTI), institusi ini bernama KOPERTIS yaitu Koordinasi Perguruan Tinggi Swasta sesuai dengan Dalam Peraturan Menteri Pendidikan dan Kebudayaan Republik Indonesia Nomor 1 Tahun 2013 tentang Organisasi dan Tata Kerja Koordinasi Perguruan Tinggi Swasta Pasal 18 disebutkan bahwa Kopertis menyelenggarakan fungsi penyusunan rencana, program, dan anggaran.

Anggaran merupakan suatu rencana kerja yang dinyatakan secara kuantitatif, yang diukur dalam satuan moneter standar dan satuan ukuran yang lain, yang mencakup satu tahun (Mulyadi, 1995 dalam Kristanto, 2009). Organisasi membutuhkan anggaran untuk menterjemahkan keseluruhan strategi ke dalam rencana operasional dan tujuan jangka pendek (Hansen dan Mowen, 1997 dalam Kristanto, 2009).

Menurut Mardiasmo (2002) dalam Widyaningsih (2011) penganggaran dalam organisasi sektor publik merupakan tahapan yang cukup rumit dan mengandung nuansa politik yang tinggi. Dalam hal anggaran merupakan instrumen akuntabilitas atas pengelolaan dana publik dan pelaksanaan program-program yang dibiayai dengan uang publik, sehingga menurut Wulandari (2016) sistem penganggaran pemerintah digunakan untuk melayani berbagai tujuan yaitu rencana manajemen, pengendalian keuangan, prioritas dari penggunaan dana, dan pertanggungjawaban kepada publik.

Anggaran sektor publik penting karena beberapa alasan, yaitu karena anggaran merupakan alat bagi pemerintah untuk mengarahkan sosial-ekonomi, menjamin kesinambungan dan meningkatkan kualitas hidup masyarakat. Disamping itu, anggaran juga diperlukan karena adanya masalah keterbatasan sumber daya sedangkan keinginan masyarakat tidak terbatas dan terus berkembang, dan anggaran juga diperlukan untuk meyakinkan bahwa pemerintah telah bertanggung jawab terhadap rakyat.

Pada saat sekarang ini pemerintah dalam proses penyusunan anggarannya menggunakan metode partisipasi, yang merupakan gabungan dari metode top down dan bottom up. Anggaran partisipatif adalah sebuah proses yang menggambarkan dimana individu-individu terlibat dalam penyusunan anggaran yang mempunyai pengaruh terhadap target anggaran, dan perlunya penghargaan atas pencapaian anggaran tersebut (Falikhatun, 2007 dalam Rukmana, 2013)

Partisipasi penganggaran merupakan 
proses dimana individu-individu, baik atasan maupun bawahan, terlibat dan mempunyai pengaruh dalam menentukan target anggaran. Partisipasi penganggaran ini diperlukan karena bawahan yang lebih mengetahui kondisi langsung bagiannya (Sujana, 2010). Menurut Lina (2015) partisipasi dalam penyusunan anggaran lebih memungkinkan bagi bawahan untuk melakukan negosiasi mengenai target anggaran yang menurut mereka dapat dicapai. Partisipasi penganggaran menyediakan kesempatan bawahan untuk berinteraksi dan berkomunikasi dengan atasannya bahkan mempengaruhi target anggaran yang ingin mereka peroleh.

\section{TINJAUAN PUSTAKA}

\subsection{Modal Psikologis}

Menurut (Luthans., 2007) mendefinisikan modal psikologis sebagai suatu keadaan perkembangan psikologis yang positif pada individu dengan karakteristik : (1) Memiliki kepercayaan diri untuk memilih dan mengerahkan upaya yang diperlukan agar berhasil pada tugas-tugas menantang (self-efficacy); (2) Membuat atribut positif tentang keberhasilan di masa kini dan mendatang (optimism); (3) Tekun dalam mencapai tujuan dan, bila diperlukan, mengalihkan cara untuk mencapai tujuan dalam rangka meraih keberhasilan (hope); dan (4) Ketika dilanda masalah dan kesulitan, individu dapat bertahan dan bangkit kembali bahkan melampaui keadaan semula untuk mencapai keberhasilan (resiliency).

Modal psikologis meliputi sumber daya mental yang dibangun individu ketika sesuatu berjalan dengan baik dan menutup ketika sesuatu berjalan tidak baik. Sumber daya ini meliputi ketahanan, motivasi, harapan, optimis, keyakinan diri, kepercayaan diri dan tenaga bekerja. Semuanya merupakan kunci dari kebahagiaan, jika karyawan tidak memiliki modal psikologis maka karyawan tersebut tidak bahagia di tempat kerja, hanya tampak dari luarnya saja (Pryce-Jones, 2010 dalam Sufya, 2015)

Menurut Prayogo (2012) modal psikologis merupakan suatu kapasitas yang terbarukan, saling melengkapi dan dapat saling bersinergis. Individu yang memiliki modal psikologis yang tinggi akan menjadi individu yang fleksibel dan adaptif untuk bertindak dengan kapasitas yang berbeda untuk memenuhi tuntutan secara dinamis.

\subsection{Anggaran}

Para ahli di bidang anggaran sepakat memberikan pengertian umum sebagai berikut : "Anggaran Negara merupakan rencana keuangan pemerintah dalam suatu waktu tertentu, biasanya dalam satu tahun mendatang, yang satu pihak memuat jumlah pengeluaran setinggi-tingginya untuk membiayai tugas-tugas negara di segala bidang, di lain pihak memuat jumlah penerimaan negara yang diperkirakan dapat menutup pengeluaran tersebut dalam periode yang sama".

Ada empat fungsi anggaran (Didit, 2011), antara lain :

1. Fungsi Perencanaan

Dalam menyusun anggaran, manajer bawah akan merencanakan kegiatankegiatanapa yang akan dilakukan di masa datang, bagaimana cara untuk melaksanakan kegiatan-kegiatan tersebut, serta bagaimana hasil yang akan dicapai dari kegiatankegiatan tersebut. Dengan adanya perencanaan tersebut, kegiatan-kegiatan yang akan dilaksanakan di masa depan diharapkan dapat terlaksana dengan baik dengan hasil yang sesuai harapan.

2. Fungsi Koordinasi

Anggaran berfungsi sebagai alat mengkoordinasikan rencana dan tindakan berbagai divisi/departemen/bagian yang ada dalam organisasi agar dapat bekerja secara selaras ke arah pencapaian tujuan.

3. Fungsi Pengawasan

Pengawasan berarti mengevaluasi 
perealisasian anggaran. Pengevaluasian tersebut dilakukan dengan cara membandingkan realisasi dengan rencana anggaran dan melakukan perbaikan bila dipandang perlu.

4. Anggaran sebagai pedoman kerja

Anggaran merupakan suatu rencana kerja yang disusun secara sistematis dan dinyatakan dalam unit moneter. Dengan anggaran, manajer dapat mengetahui tindakan-tindakan apa saja yang akan dilakukan.

\subsection{Partisipasi Anggaran}

Partisipasi anggaran adalah sebuah proses yang menggambarkan dimana individu-individu terlibat dalam penyusunan anggaran yang mempunyai pengaruh terhadap target anggaran, dan perlunya penghargaan atas pencapaian anggaran tersebut (Falikhatun, 2007 dalam Rukmana, 2013).

Menurut Pamungkas, dkk 2014 partisipasi penganggaran melibatkan semua tingkatan manajemen untuk mengembangkan rencana anggaran. Partisipasi penganggaran ini diperlukan karena bawahan yang lebih mengetahui kondisi langsung bagiannya. Dengan demikian, tujuan perusahaan akan lebih dapat diterima jika seluruh anggota organisasi dapat bersama-sama dalam suatu kelompok untuk saling bertukar pendapat dan informasi mengenai tujuan perusahaan dan terlibat dalam menentukan langkahlangkah untuk mencapai tujuan tersebut.

Partispasi anggaran merupakan suatu proses dalam organisasi yang melibatkan para manajer tingkat bawah dalam penentuan tujuan anggaran yang menjadi tanggung jawab mereka (Sugiartha, dkk 2014), sementara Anggraeni (2008) dalam Sugiartha,dkk (2014) memandang bahwa partisipasi anggaran sebagai proses memberikan kesempatan kepada bawahan/pelaksana anggaran untuk terlibat dalam proses penyusunan anggaran.

Partisipasi anggaran membutuhkan keikutsertaan lebih banyak manajer dalam proses penyusunannya. Tidak hanya manajer tingkat atas, tetapi juga manajer tingkat bawah. Dengan adanya keterlibatan tersebut, mereka akan merasa lebih dihargai dan merasa bahwa ide-idenya dibutuhkan oleh organisasi (Ferdiani, 2012)

Menurut Murray dalam Sumarno (2005) menyatakan bahwa partisipasi dari bawahan dalam penyusunan anggaran mempunyai konsekuensi terhadap sikap dan perilaku anggota organisasi yang selanjutnya akan mempengaruhi kinerja dari anggota organisasi tersebut.

Manfaat partisipasi anggaran (Arfan, 2011) adalah sebagai berikut:

1. Partisipasi anggaran membuat manajer bawah merasa dihargai oleh perusahaan karena manajer bawah dapat terlibat dan memberikan pengaruh pada penetapan anggaran final.

2. Partisipasi anggaran mendorong inisiatif yang lebih besar karena manajer bawah ikut berpikir dan memberikan ide-ide dan pendapatnya kepada manajer atas.

3. Partisipasi anggaran dapat meningkatkan rasa kesatuan kelompok sehingga kerjasama antar kelompok dlam penetapan tujuan organisasi cenderung meningkat. Hal ini karena manajer bawah dan manajer puncak bersama-sama berpikir dan salih bertukar pikiran dalam menentukan anggaran sehingga anggaran yang ditetapkan dapat diterima oleh manajer bawah dan manajer atas. Tujuan perusahaan yang dibantu penetapannya oleh manajer bawah dipandang sebagai tujuan yang selaras dengan tujuan dengan tujuan pribadi manajer bawah yang disebut sebagai internalisasi tujuan.

4. Partisipasi anggaran dapat menurunkan tekanan dan kegelisahan terkait target anggaran yang harus dicapai manajer bawah. Dengan adanya partisipasi anggaran, manajer bawah ikut 
menentukan anggaran dengan mengajukan usulan anggaran kepada manajer atas sehingga target anggaran tersebut sesuai dengan kemampuan manajer bawah yang sebenarnya.

5. Partisipasi anggaran dapat menurunkan ketidakadilan serta reaksi negatif atas persepsi ketidakadilan tersebut.

\subsection{Senjangan Anggaran}

Salah satu kelemahan partisipasi penganggaran yaitu timbulnya senjangan anggaran (Fitri, 2007). Senjangan anggaran adalah perbedaan jumlah anggaran yang diajukan oleh bawahan dengan jumlah estimasi yang terbaik dari organisasi (Anthony dan Govindarajan, 2005 dalam Rukmana, 2013). Menurut Anggraeni (2008) senjangan anggaran adalah perbedaan/selisih antara sumber daya yang sebenarnya dibutuhkan dengan sumber daya yang diajukan dalam anggaran. Sementara itu, menurut Triana (2012) senjangan anggaran merupakan perbedaan antara jumlah anggaran dengan estimasi terbaik. Senjangan anggaran biasanya dilakukan dengan meninggikan biaya atau menurunkan pendapatan dari yang seharusnya.

Tiga penyebab utama manajer melakukan senjangan anggaran menurut Falikhatun (2007) adalah :

1. Orang-orang yang selalu percaya bahwa hasil pekerjaan mereka akan terlihat bagus di mata atasan jika mereka mencapai anggarannya.

2. Senjangan anggaran selalu digunakan untuk mengatasi kondisi ketidakpastian. Jika tidak ada kejadian yang tidak terduga, yang terjadi manajer tersebut dapat melampaui/mencapai anggarannya.

3. Rencana anggaran selalu dipotong dalam proses pengalokasian sumber daya.

Dalam proses penganggaran sektor publik, manajemen tingkat atas hingga manajemen tingkat bawah terlibat secara langsung dalam penyusunan suatu anggaran dalam kurun periode tertentu. Bagi yang terlibat secara langsung dalam proses penyusunan anggaran tersebut akan mempunyai suatu akibat langsung yang akan dirasakan terhadap perilaku manusia. Terdapat perilaku-perilaku manusia yang mungkin timbul sebagai akibat dari partisipasi anggaran. Perilaku yang positif dapat berupa peningkatan kinerja manajer karena termotivasi oleh anggaran yang digunakan sebagai dasar penilaian kinerja mereka. Perilaku negatif yang mungkin timbul adalah kecenderungan manajer untuk menciptakan senjangan dalam anggaran (Maya Triana, 2012). Sehingga dalam penelitian ini modal psikologis juga dikaitkan dengan senjangan anggaran. Modal psikologis didefinisikan sebagai suatu kondisi psikologis yang positif pada individu yang terdiri dari sejumlah komponen kepercayaan diri, keyakinan, harapan, dan resiliensi ketika seorang individu berusaha mencapai kesuksesan (Sufya, 2015).

Menurut Venkatesh dan Blaskovich (2012) dalam Lina (2015) menyatakan bahwa modal psikologis berfokus pada pengembangan dan pembangunan kekuatan individu dalam upaya berkonsentrasi pada proses pengurangan atau eliminasi kelemahan individu. Modal psikologis bersifat positif dan mencakup perkembangan level individual terkait dengan efikasi diri, optimis, harapan dan resiliensi. Modal psikologis merupakan keadaan psikologis yang positif pada diri individu yang ditandai dengan karakteristik efikasi diri, optimisme, resiliensi dan harapan (Luthans F, 2007). Karakteristik-karakteristik inilah yang mempengaruhi perilaku-perilaku manusia dalam proses penyusunan anggaran. Kristanto (2009) telah melakukan penelitian yang menguji pengaruh antara Budget Participation terhadap Budgetary Slack (Survei pada Manajer Perusahaan Manufaktur di Indonesia). Hasil penelitian 
menunjukkan bahwa adanya pengaruh yang signifikan antara partisipasi penganggaran dengan senjangan anggaran.

\section{METODOLOGI PENELITIAN}

3.1 Gambaran Umum Lembaga Layanan Pendidikan Tinggi (LLDIKTI)

Lembaga Layanan Pendidikan Tinggi berdasarkan Permenristekdikti Nomor 15 tahun 2018 sesuai pasal 1, berkedudukan berada di bawah dan bertanggungjawab kepada Menteri yang dipimpin oleh seorang Kepala. Dalam melaksanakan tugasnya, Lembaga Layanan Pendidikan Tinggi menyelenggarakan fungsi sebagai berikut:

1. Pelaksanaan pemetaan mutu pendidikan tinggi di wilayah kerjanya;

2. Pelaksanaan fasilitasi peningkatan mutu penyelenggaraan pendidikan tingi di wilayah kerjanya;

3. Pelaksanaan fasilitasi peningkatan mutu pengelolaan perguruan tinggi di wilayah kerhanya;

4. Pelaksanaan fasilitasi kesiapan perguruan tinggi dalam penjaminan mutu eksternal di wilayah kerjanya;

5. Pelaksanaan evaluasi dan pelaporan pelaksanaan fasilitasi peningkatan mutu perguruan tinggi di wilayah kerjanya;

6. Pengelolaan dan informasi di bidang mutu pendidikan tinggi di wilayah kerjanya; dan

7. Pelaksanaan administrasi LLDIKTI.

Tugas dan fungsi Lembaga Layanan Pendidikan Tinggi Wilayah II sebagaimana di atur dalam Peraturan Menteri Riset, Teknologi, dan Pendidikan Tinggi Nomor 15 Tahun 2018 tentang Organisasi dan Tata Kelola Lembaga Layanan Pendidikan Tinggi sebagai upaya mendukung program peningkatan sumber daya manusia Indonesia yang berkualitas menuju Indonesia maju.

Sampai dengan saat ini terdapat 14 LLDIKTI di seluruh Indonesia dengan perincian sebagai berikut:

1. LLDIKTI Wilayah I Medan

2. LLDIKTI Wilayah II Palembang
3. LLDIKTI Wilayah III Jakarta

4. LLDIKTI Wilayah IV Bandung

5. LLDIKTI Wilayah V Yogyakarta

6. LLDIKTI Wilayah VI Semarang

7. LLDIKTI Wilayah VII Surabaya

8. LLDIKTI Wilayah VIII Bali

9. LLDIKTI Wilayah IX Ujung Pandang

10. LLDIKTI Wilayah X Padang

11. LLDIKTI Wilayah XI Banjarmasin

12. LLDIKTI Wilayah XI Ambon

13. LLDIKTI Wilayah XIII Aceh

14. LLDIKTI Wilayah XIV Papua

\subsection{Jenis Penelitian}

Pendekatan penelitian ini berdasarkan pendekatan survey. Pendekatan survey adalah penelitian yang mengambil sampel dari satu populasi dan menggunakan kuesioner sebagai alat pengumpulan data yang pokok dan mengumpulkan data mengenai faktor-faktor yang berkaitan dengan variabel penelitian (Singarimbun \& Sofian, 2006).

Jenis penelitian ini adalah deskriptif komparatif, yaitu penelitian yang dilakukan untuk mengetahui nilai variabel mandiri, baik satu variabel atau lebih (independen) dengan membuat perbandingan atau menghubungkan dengan variabel lain (Sugiyono, 2009).

\subsection{Populasi dan Sampel}

1. Populasi

Populasi dalam penelitian ini adalah LLDIKTI di seluruh Indonesia. Terdapat 14 LLDIKTI di seluruh Indonesia.

2. Sampel

Kriteria sampel dalam penelitian ini adalah:

1) Pejabat Eselon IV dan Tim Penyusunan Perencanaan Program dan Anggaran di Kantor LLDIKTI di Seluruh Indonesia.

2) Pihak-pihak tersebut juga terlibat di dalam penyusunan 
program dan anggaran pada Kantor LLDIKTI.

\subsection{Metode Pengumpulan Data}

Jenis data yang digunakan dalam penelitian ini adalah data primer, yaitu data yang dikumpulkan oleh peneliti langsung dari sumber pertama. Teknik pengumpulan data yang dilakukan dalam penelitian ini adalah dengan membagikan kuesioner.

\section{HASIL DAN PEMBAHASAN}

\subsection{Pengaruh modal psikologis terhadap keinginan untuk membuat senjangan anggaran}

Tabel 1

Hasil Uji Statistik t dengan 2 variabel independen

\begin{tabular}{|l|l|l|l|l|}
\hline Variabel & $\mathbf{N}$ & $\mathbf{T}$ & $\begin{array}{c}\text { Sig } \\
\mathbf{2} \\
\text { tailed })\end{array}$ & Keterangan \\
\hline $\begin{array}{l}\text { Modal } \\
\text { Psikologis }\end{array}$ & 84 & 992 & 0,050 & Signifikan \\
\hline $\begin{array}{l}\text { Partisipasi } \\
\text { Anggaran }\end{array}$ & 84 & 778 &, 079 & Tidak Signifikan \\
\hline
\end{tabular}

Sumber : Diolah dari data primer, 2019. Menggunakan SPSS 20 For Windows.

Berdasarkan hasil uji $\mathrm{t}$ dengan 2 variabel independen diketahui bahwa modal psikologis berpengaruh terhadap keinginan untuk membuat senjangan anggaran, dengan nilai t hitung 1,992 dan nilai Sig sebesar 0,050.Hal ini menunjukkan bahwa t hitung lebih besar daripada $t$ tabel 1,9896 dan nilai Sig sama dengan 0,05. Artinya hipotesis pertama $\left(\mathrm{H}_{1)}\right.$ yang menyatakan bahwa terdapat pengaruh modal psikologis terhadap keinginan untuk membuat senjangan anggaran di Kantor LLDIKTI seluruh Indonesia, didukung. Temuan ini menunjukkan bahwa semakin tinggi modal psikologis, maka keinginan untuk membuat senjangan anggaran akan semakin tinggi.

Hasil penelitian tersebut dapat dijelaskan lebih lanjut dari hasil uji $t$ dengan 5 variabel independen dimana komponen dalam modal psikologis yang terdiri dari efikasi diri, optimis, harapan dan resiliensi dijadikan sebagai variabel independen. Berdasarkan hasil uji $t$ dengan 5 variabel independen diketahui bahwa hanya komponen resiliensi yang berpengaruh terhadap keinginan untuk membuat senjangan anggaran dengan nilai $\mathrm{t}$ hitung 2,183 dan nilai Sig sebesar 0,032. Hal ini menunjukkan bahwa t hitung lebih besar daripada $t$ tabel 1,9896 dan nilai Sig lebih kecil dari 0,05 .

Senjangan anggaran yang dilakukan oleh penyusun rencana dan anggaran tidak untuk kepentingan pribadi akan tetapi untuk kepentingan instansi agar kegiatan yang telah direncanakan tetap berjalan. Seperti hasil uji $\mathrm{t}$ dengan 5 variabel independen yang membuktikan bahwa komponen resiliensi yang berpengaruh terhadap keinginan untuk membuat senjangan anggaran. Hal ini terbukti ketika terdapat kebijakan pemerintah pusat untuk melakukan efisiensi anggaran yang berupa pemotongan anggaran di tengah tahun berjalan, dengan melakukan senjangan anggaran diharapkan kegiatan instansi tetap berjalan meskipun terdapat pemotongan anggaran.

\subsection{Pengaruh partisipasi anggaran terhadap keinginan untuk membuat senjangan anggaran}

Tabel 2

Hasil Uji Statistik t dengan 5 variabel independen

\begin{tabular}{|l|l|l|l|c|}
\hline Variabel & $\mathbf{N}$ & $\mathbf{T}$ & $\begin{array}{c}\text { Sig } \\
\mathbf{2} \text { tailed })\end{array}$ & Keterangan \\
\hline $\begin{array}{l}\text { Efikasi } \\
\text { Diri }\end{array}$ & 84 & 0,811 & 0,420 & $\begin{array}{c}\text { Tidak } \\
\text { Signifikan }\end{array}$ \\
\hline Optimis & 84 & $-0,782$ & 0,437 & $\begin{array}{c}\text { Tidak } \\
\text { Signifikan }\end{array}$ \\
\hline Harapan & 84 & 1,057 & 0,294 & $\begin{array}{c}\text { Tidak } \\
\text { Signifikan }\end{array}$ \\
\hline Resiliensi & 84 & 2,183 & 0,032 & \begin{tabular}{c} 
Signifikan \\
\hline $\begin{array}{l}\text { Partisipasi } \\
\text { Anggaran }\end{array}$
\end{tabular} \\
$\begin{array}{l}\text { Sumber : Diolah dari data primer, 2019. Menggunakan } \\
\text { SPSS 20 For Windows. }\end{array}$ & 1,778 & 0,098 & $\begin{array}{c}\text { Tidak } \\
\text { Signifikan }\end{array}$ \\
\hline
\end{tabular}




Berdasarkan hasil uji t diketahui
bahwa partisipasi anggaran tidak
berpengaruh terhadap keinginan untuk
membuat senjangan anggaran, dengan nilai t
hitung 1,778 dan nilai Sig sebesar 0,079 . Hal
ini menunjukan bahwa t hitung lebih kecil
daripada t tabel 1,9896 dan nilai Sig lebih
besar dari 0,05 . Artinya hipotesis kedua $\left(\mathrm{H}_{2}\right)$
yang menyatakan bahwa Terdapat pengaruh
partisipasi anggaran terhadap keinginan
untuk membuat senjangan anggaran di
Kantor Kopertis seluruh Indonesia, tidak
didukung. Temuan ini menunjukkan bahwa
partisipasi anggaran tidak berpengaruh
terhadap keinginan untuk membuat
senjangan anggaran. Secara empiris
senjangan anggaran tetap dilakukan.

Senjangan anggaran tidak dilakukan secara nominal tetapi secara frekuensi dan jumlah unit.

Hal ini sejalan dengan penelitian Sujana (2010) yang mengindikasikan bahwa partisipasi anggaran tidak mempunyai pengaruh terhadap senjangan anggaran. Dan tidak sejalan dengan penelitian Kristanto (2009), Sugiartha, dkk (2014), Pamungkas, dkk (2014), dan Rukmana (2013) yang mengindikasikan bahwa tingkat partisipasi yang tinggi akan menurunkan kesenjangan anggaran.

Penelitian ini tidak sesuai dengan yang dilakukan Widyaningsih (2011), Marfuah, dkk (2014) dan Triana, dkk (2012) yang menyatakan semakin tinggi partisipasi maka semakin tinggi pula terjadinya senjangan anggaran.

\section{KESIMPULAN}

Berdasarkan pengolahan data dan hasil analisis data maka dapat disimpulkan bahwa terdapat pengaruh modal psikologis terhadap keinginan untuk membuat senjangan anggaran. Individu yang memiliki modal psikologis yang tinggi akan menjadi individu yang flesibel dan adaptif untuk bertindak dengan kapasitas yang berbeda untuk memenuhi tuntutan secara dinamis. Tuntutan dalam hal ini adalah kebijakan dari pemerintah pusat yang berupa efisiensi anggaran. Dan tidak terdapat pengaruh partisipasi anggaran terhadap keinginan untuk membuat senjangan anggaran. Tidak semua LLDIKTI menerapkan sistem partisipasi anggaran. Beberapa LLDIKTI terdapat tim penyusunan perencanaan program dan anggaran yang terdiri dari Kepala Bagian Umum dan staf subbag keuangan dimana setiap unit penanggung jawab kegiatan hanya mengusulkan kegiatan untuk penyusunan anggaran dilakukan tim tersebut, sedangkan LLDIKTI yang lain untuk penyusunan perencanaan program dan anggaran diajukan oleh masing-masing unit penanggung jawab kegiatan.

\section{SARAN}

Berdasarkan kesimpulan diatas maka saran dari penelitian ini, yaitu dari hasil penelitian ini terlihat bahwa partisipasi penyusunan anggaran berpengaruh terhadap senjangan anggaran. Untuk lebih meminimalisir kecenderungan aparat dalam melakukan senjangan anggaran dan diharapkan aparat dapat meningkatkan komunikasi yang positif dengan atasannya. Bagi peneliti lain yang tertarik untuk meneliti judul yang sama, maka peneliti menyarankan agar dapat menambahkan variabel lain seperti variabel kejelasaan sasaran anggaran, penekanan anggaran dan kecukupan anggaran.

\section{DAFTAR PUSTAKA}

[1] Anggraeni, R. S. (2008). Pengaruh Partisispasi Anggaran, Information Asymetry, dan Budget Emphasis terhadap Slack Anggaran (Studi pada PT. Jasa Raharja (Persero) Cabang Daerah Istimewa Yogyakarta. Skripsi. Universitas Islam Indonesia Yogyakarta.

[2] Arfan, I. (2008). Metodologi 
Penelitian Akuntansi Keperilakuan.

Yogyakarta: Graha Ilmu.

[3] Arfan, I. (2011). Akuntansi Keperilakuan. Jakarta: Salemba Empat.

[4] Diana Eka Wulandari, d. (2016). Pengaruh Penganggaran Partisipatif terhadap Kinerja Manajerial dengan Komitmen Organisasi dan Gaya Kepemimpinan. Jurnal Ilmu dan Riset Akuntansi, Volume 5., Nomor 4.

[5] Didit, H. (2011). teknik Penyusunan Anggaran Operasional Perusahaan. Yogyakarta: Gosyen Publishing.

[6] Dunk, A. S. (1993). The Effect of Budget Emphasis and Information Asymmetry on the Relation between Budgetary Participation and Slack. The Accounting Review, Vol.68., No. 2, 400-410.

[7] Falikhatun. (2007). Pengaruh Partisipasi Penganggaran terhadap Budgetary Slack dengan Variabel Pemoderasi Ketidakpastian Lingkungan dan Kohesivitas Kelompok. Jurnal Akuntansi dan Keuangan, Volume 6., No.2.

[8] Ferdiani, D. (2012). Pengaruh Partisipasi Anggaran Terhadap Kinerja Manajerial Pegawai Sekretariat Daerah Provinsi Jawa Tengah : Komitmen Organisasi dan Persepsi Inovasi sebagai Variabel Intervening. Skripsi, Universitas Diponegoro.

[9] Fitri, Y. (2007). Senjangan Anggaran : Pengaruh Informasi Asimetri, Partisipasi Penganggaran dan Komitmen Organisasi (Studi Empiris pada Universitas Swasta di Kota
Bandung). Jurnal Ichsan Gorontalo, Volume 2., No.3.

[10] Ghozali, I. (2009). Aplikasi Multivariate dengan Program SPSS Edisi.4. Semarang: badan Penerbit Universitas Diponegoro.

[11] Hariningtyas, R. A. (2014). Pengaruh Asimetri Informasi terhadap Senjangan Anggaran pada Penganggaran Partisipatif dengan Orientasi Etika sebagai Variabel Moderating. Skripsi, Universitas Negeri Yogyakarta.

[12] I Made Bagas Pamungkas, I. M. (2014). Pengaruh Partisipasi Anggaran, Informasi Asimetri, Budaya Organisasi, Kompleksitas Tugas, Reputasi, Etika, dam Self Esteem terhadap Budgetary Slack ( Studi Kasus pada Satuan Kerja Perangkat Daerah Kabupaten Jembrana). e-Journal S1 Ak Universitas Pendidikan Ganesha.

[13] I Putu Teguh Sugiartha, N. T. (2014). Pengaruh Anggaran Partisipatif, terhadap Budgetary Slack dengan Informasi Asimetri sebagai Pemoderasi pada Pemerintah Kabupaten Buleleng. e-Journal S1 Akuntansi universitas Pendidikan Ganesha.

[14] Iwan Hanafi Liwarto, A. K. (2015). Hubungan Psycap dengan Kinerja Karyawan PT. X Bandung. Jurnal Manajemen, Vol. 14., No.2, 222-244.

[15] Kren, L. (1992). Budgetary Participation and Managerial Performance : The Impact of Information and Enviromental Volatility. The Accounting Review, Vol.67., No.3, 511-526. 
[16] Kristanto, D. (2009). Analisis Pengaruh antara Budget Participation terhadap Budgetary Slack pada Manajer Perusahaan Manufaktur di Indonesia. Jurnal Manajemen Sumberdaya Manusia Vol. 3 No. 1 , 33 - 39.

[17] Lina. (2015). Partisipasi Penyusunan Anggaran, Psychological Capital, dan Kinerja Manajerial. Jurnal Manajemen Teknologi, Vol.14, No.3.

[18] Luthans., F. Y. (2007). Psychological Capital : Developing The Human Competitive Edge . New York : Oxford University Press.

[19] Marfuah, A. L. (2014). Pengaruh Partisipasi Anggaran terhadap Senjangan Anggaran dengan Menggunakan Komitmen Organisasi, dan Informasi Asimetri sebagai Variasi Pemoderasi. EKBISI, Vol. VIII, No. 2, 200-218.

[20] Maya Triana, Y. W. (2012). Pengaruh Partisipasi Anggaran, Budget Emphasis, dan Locus of Control Terhadap Slack Anggaran (Survei pada Hotel Berbintang di Kota Jambi). e-Jurnal Binar Akuntansi, Vol.1., No. 1, 53-56.

[21] Ozer, G. d. (2011). Effects of Procedural Justice Perception, Budgetary Control Effectiveness and Ethical Work Climateon Propensity to Creat Budgetary Slack. Business and Economics Research Journal, Vol. 2 Number 4,pp. 1-18.

[22] Peraturan Menteri Pendidikan dan Kebudayaan Republik Indonesia No. 1 tahun 2013 tentang Organisasi dan Tata Kerja Kopertis. 2013. Jakarta: Kementrian Pendidikan dan
Kebudayaan Republik Indonesia.

[23] Rukmana, P. (2013). Pengaruh Partisipasi Anggaran dan Asimetri Informasi terhadap Timbulnya Budget Slack.

[24] Siriporn Sapyaprapa, A. T. (2013). Validation of Psychological Capital Questionnary in Thai Employees . The Asian Conference on Psychology \& Behavioral Sciences.

[25] Sufya, D. h. (2015). Pengaruh Modal Psikologis, Budaya Organisasi, dan Spiritualitas di Tempat Kerja teradap Organizational Citizenship Behavior. Tesis.

[26] Sugiyono. (2009). Statistika untuk Penelitian. Bandung: Alfabeta.

[27] Sujana, I. K. (2010). Pengaruh Partisipasi Penganggaran, Penekanan Anggaran, Komitmen Organisasi, Asimetri Informasi, dan Ketidakpastian Lingkungan terhadap Budgetary Slack pada Hotel-Hotel berbintang di Kota Denpasar.

[28] Sumarno, J. (2005). Pengaruh Komitmen Organisasi dan Gaya Kepemimpinan Terhadap Hubungan antara Partisipasi Anggaran dan Kinerja Manajerial (Studi Empiris pada Kantor Cabang Perbankan Indonesia di Jakarta). Jurnal Bisnis Strategi, Vol.14., No. 2.

[29] Undang-Undang Republik Indonesia Nomor 17 tahun 2003 tentang Keuangan Negara. 2003. Jakarta: Kementrian Keuangan Republik Indonesia.

[30] Undang-Undang Republik Indonesia Nomor 1 tahun 2004 tentang 
Perbendaharaan Negara. 2004.

Jakarta: Kementrian Keuangan

Republik Indonesia.

[31] Undang-Undang Republik Indonesia Nomor 15 tahun 2004 tentang

Pemeriksaan Pengelolaan dan Tanggung Jawab Keuangan Negara. 2004. Jakarta: Kementrian Keuangan Republik Indonesia.

[32] Widyaningsih, A. (2011). Moderasi Gaya Kepemimpinan atas Pengaruh Partisipasi Anggaran terhadap Budgetary Slack. 